\section{МАТЕМАТИЧНЕ МОДЕЛЮВАННЯ В СИСТЕМІ ЕКОНОМІЧНОÏ ОСВІТИ ${ }^{\odot}$}

\author{
НОВИЦЬКА Л.І., \\ кандидат педагогічниих наук, \\ доцент кафедри математики, фізики \\ ма комп'ютерних технологій, \\ Вінницький національний \\ аграрний університет \\ (м. Вінниця)
}

Важливою складовою професійної підготовки майбутніх економістів є підвищення їхнього рівня математичної освіти. Це передбачає розуміння суті основних понять, ідей $і$ методів, які вивчаються в курсі вищої математики, їх тлумачення в економічних науках, уміння та навичок будувати математичні моделі застосовувати математичні методи для розв'язання професійноорієнтованих задач. У статті визначено роль вищої математики як важливого інструментарію ефективної діяльності економіста. Розглянуто питання про необхідність навчання студентів економічних спеціальностей вищих навчальних закладів математичному моделюванню як засобу здійснення професійно-спрямованого викладання вищої математики. Обтрунтовано доиільність використання прикладних задач, які демонструють необхідність введення основних математичних понять, підвищують мотивацію й стимулюють вивчення дисципліни, сприяють розвитку дослідницьких навичок майбутніх фахівців.

Ключові слова: економічна освіта, вища математика, математичне моделювання, математична модель, прикладні задачі, професійно-орієнтовані завдання.

Літ.: 8.

\title{
MATHEMATICAL MODELING IN THE SYSTEM OF ECONOMIC EDUCATION
}

\author{
NOVYTSKA Lyudmyla, \\ Candidate of Pedagogical Sciences, Associate Professor \\ of the Department of Mathematics, Physics and Computer Technologies, \\ Vinnytsia National Agrarian University \\ (Vinnytsia)
}

An important component of the training of future economists is to increase their level of mathematical education. This involves understanding the essence of the basic concepts, ideas and methods that are studied in the course of higher mathematics, their interpretation in methods to solve professionally-oriented tasks. The article describes the role of higher mathematics as an important tool for effective work of an economist. The article considers the necessity of teaching students of economic specialties of higher educational establishments to mathematical modeling as a means of professionaloriented teaching of higher mathematics. The expediency of using applied problems, which demonstrate the necessity of introducing basic mathematical concepts, raises motivation and stimulates the study of discipline, promotes development of research skills of future specialists.

Key words: economic education, higher mathematics, mathematical modeling, mathematical model, applied problems, professionally-oriented tasks.

Ref.: 8.

\section{МАТЕМАТИЧЕСКОЕ МОДЕЛИРОВАНИЕ В СИСТЕМЕ ЭКОНОМИЧЕСКОГО ОБРАЗОВАНИЯ}

НОВИЦКАЯ Людмила Ивановна, кандидат педагогических наук, доцент кафедры математики, физики и компьютерных технологий, Винницкий национальный аграрный университет (2. Винница) 
Важной составляющей профессиональной подготовки будущих экономистов является повымение их уровня математического образования. Это предполагает понимание сути основных понятий, идей и методов, которые изучаются в курсе высшей математики, их толкование в экономических науках, умения и навыки строчть математические модели, применять математические методы для решения профессионально-ориентированных задач. В статье определена роль высшей математики как важного инструментария эффективной деятельности экономиста. Рассмотрены вопросы о необходимости обучения студентов экономических специальностей высших учебных заведений математическому моделированию как средства осуществления профессионально-направленного преподавания высшей математики. Обоснована целесообразность использования прикладных задач, которые демонстрируют необходимость введения основных математических понятий, повымают мотивацию и стимулируют изучение дисциплины, способствуют развитию исследовательских навыков будущих специиалистов.

Ключевые слова: экономическое образование, высшая математика, математическое моделирование, математическая модель, прикладные задачи, профессионально-ориентированные задания.

Лит.: 8.

Постановка проблеми. Економічна освіта як сфера надзвичайно важливої соціальноекономічної діяльності є стратегічним ресурсом розвитку національної економіки, забезпечення зростання іiі конкурентоспроможності в умовах швидкоплинних трансформаційних змін глобального характеру.

Сьогодні ринок праці переповнений випускниками економічних спеціальностей, але існує попит на фахівців, що відповідають глобалізаційним та інтеграційним викликам, вимогам ринкової економіки.

Перед закладами вищої освіти (ЗВО) постає проблема з підготовки фахівців-економістів нової генерації, здатних ефективно працювати в сучасних умовах, знаходити й сміливо приймати оптимальні рішення, активно їх впроваджувати у життя, мати високий інтелектуальний та творчий потенціал, професійну мобільність і професіоналізм, конкурувати на світовому ринку праці, створювати та вести власний бізнес, керувати підприємством, тобто володіти творчим мисленням на фоні високої індивідуальної компетентності.

Математизація різних галузей знань, впровадження інформаційно-комунікаційних технологій (IKT), ускладнення виробничих і технологічних процесів, необхідність аналізу й обробки великих обсягів інформації для успішного прийняття рішень та прогнозування призводять до необхідності побудови математичних моделей різної складності.

Можливість використання засобів моделювання зумовлена тим, що вміння моделювати пов'язане з оволодінням такими мисленнєвими операціями як аналіз, синтез, аналогія, порівняння, узагальнення тощо. Дослідженням установлено, що етапи моделювання сприяють розвитку розумових, творчих і математичних здібностей студентів у формуванні наукового мислення, підвищенню ефективності засвоєння знань, забезпеченню високого рівня математичної підготовки [1, с.105]. Тому студенти, які будують та досліджують моделі, можуть досягнути високого рівня творчості.

Отож, впровадження у навчальний процес елементів математичного моделювання $є$ одним із ефективних засобів удосконалення фахової підготовки майбутніх економістів у процесі навчання математичним дисциплінам.

Аналіз останніх досліджень і публікацій. Широкий спектр питань навчання математики студентів ВН3, зокрема питання, пов'язані 3 використанням математичного моделювання, досліджені Л.П. Гусак [1], Г.Я. Дуткою [2], Л.І. Нічуговською [3], К.Є. Румянцевою [4], Ю.М. Ткач [5], О.Г. Фомкіною [6] та ін.

Так Г.Я. Дутка зазначає, що в умовах професійної освіти класичні курси математики мають бути не тільки професійно зорієнтованими, а й формувати фундаментальну основу для професійних і спеціальних знань. При цьому логіка математичної науки, цілісність курсу математики має бути збережена й передана студентам. Методика викладання математичних дисциплін має поступово, залежно від рівня підготовки студентів, вводити їх у сферу застосування математики в економічному аналізі [2, с. 271].

Однак студенти-першокурсники економічних спеціальностей ЗВО методи математичного моделювання вивчають опосередковано та епізодично.

Аналіз наукової та методичної літератури, стану практичної підготовки студентів свідчить, що проблема формування готовності майбутніх економістів до застосування методів математичного моделювання ще недостатньо досліджена в теоретичному та практичному аспектах. 
Формулювання цілей статті. Мета статті: на підставі практичного досвіду викладання вищої математики для студентів-економістів Вінницького національного аграрного університету (BНАУ) визначити місце і роль математичного моделювання у процесі математичної підготовки фахівців у сучасних умовах розвитку економіки в Україні.

Виклад основного матеріалу дослідження. Вища математика посідає особливе місце у соціально-економічних дослідженнях. Сучасний фахівець у галузі економіки має бути спроможним до вирішення виробничих та управлінських завдань, уміти аналізувати та прогнозувати економічні процеси тощо. Одним із напрямів підвищення якості підготовки фахівців економічного профілю $\epsilon$ забезпечення професійно-спрямованого викладання вищої математики.

Вища математика вивчається студентами економічних спеціальностей протягом першого року навчання i має на меті забезпечити їх фундаментальними знаннями, стати базовою дисципліною для подальшого засвоєння суміжних та фахових дисциплін: макроекономіки, мікроекономіки, економічного аналізу, фінансів підприємства, інформатики та комп'ютерної техніки та ін. Особливо насиченими математичним апаратом $\epsilon$ навчальні дисципліни «Економетрика», «Статистика», «Дослідження операцій», «Прикладні задачі моделювання економічних процесів» та ін. Тому спрямовувати майбутнього економіста на успішне застосування математичних методів починати потрібно саме на заняттях з вищої математики.

Основною концепцією викладання вищої математики для студентів-економістів у межах виділеного навчального часу має бути логічно стуктуроване й комплексне вивчення основних понять, ідей, методів класичних розділів математики та реалізація їх зв'язків із актуальними завданнями ринкової економіки, фаховими дисциплінами.

При цьому варто прагнути, щоб зв’язки математичних понять, методів з економічними задачами були обгрунтованими, а не штучно надуманими. Зрозуміло, що деякі математичні поняття та методи не використовуються широко в економічних дослідженнях і викладаються студентам лише через необхідність збереження логічної послідовності програми дисципліни (границя послідовності та функції, неперервність функції та ін.).

Однак низка математичних понять і методів досить поширені при аналізі економічних явищ (матриці, системи лінійних алгебраїчних рівнянь, функції однієї та багатьох змінних, похідна, інтеграл, диференціальні рівняння та ін.), і тому в процесі їхнього викладання доцільно знайомити студентів з основними аспектами таких застосувань.

Реалізацію описаної концепції варто починати з розробки робочої навчальної програми дисципліни, у якій необхідно передбачити найпоширеніші математичні моделі, а також розв'язування прикладних задач із застосуванням математики в економічних процесах. Кожне нове поняття доцільно вводити лише після розгляду різноманітних задач, які й призводять до необхідності введення саме цього поняття.

Очевидно, що в межах однієї статті неможливо продемонструвати реалізацію цієї концепції повністю. Зосередимо увагу на окремих ії положеннях.

Найбільш розповсюдженими в економіці є матричні моделі, які успішно застосовуються під час аналізу й планування виробництва, оскільки вони просто та наочно відображають властивості різних об'єктів. У процесі вивчення розділу «Лінійна алгебра» необхідно звернути увагу студентів на те, що за допомогою дії додавання матриць послідовні ланки виробництва з'єднуються в єдиний взаємопов'язаний ланцюжок, а для одночасного відображення технологічної й організаційної структури використовують властивості дії множення матриць.

На основі теоретичних положень розділу «Аналітична геометрія» за допомогою рівняння прямої на площині побудовано математичну модель рівноваги доходів і збитків підприємства. За допомогою ліній першого і другого порядків аналізуються питання збитковості та прибутковості виробництва, рентабельність транспортних перевезень, співвідношення між затратами праці і виробничих ресурсів.

Розділ «Диференціальне числення» широко використовується в економічному аналізі. Задачі на обчислення граничних витрат виробництва, граничного прибутку, граничної корисності розв'язуються шляхом диференціювання відповідних економічних функцій. Клас задач на знаходження оптимальних значень економічних показників (наприклад, найвища продуктивність, максимальний прибуток, мінімальні витрати та ін.) також потребують використання апарату диференціального числення. На основі цього розділу в економіці введено поняття еластичності функції, яке використовують для аналізу попиту та споживання, прогнозів цінової політики.

За допомогою використання теоретичних положень розділу «Інтегральне числення» можна визначити приріст капіталу за відомими інвестиціями, ступінь нерівномірності розподілу доходів населення, обчислити середні значення економічних функцій тощо. 
Диференціальні рівняння - широко застосовуваний апарат для дослідження різних процесів в економічних дослідженнях. В економіці диференціальні рівняння використовуються для опису динаміки чисельності населення, при моделюванні проблем інфляції, державного боргу, економічного зростання, безробіття, взаємозв'язків грошового і реального ринків.

Тому студентам-економістам потрібно довести необхідність вивчення вказаних розділів вищої математики для успішного оволодіння фаховими дисциплінами, а також для розвитку вміння аналізувати економічні процеси, описані відповідним математичним апаратом.

Більшість сучасних математиків-методистів вважає, що розв'язання прикладної задачі 3 елементами математичного моделювання включає три основні етапи: 1) математичне формулювання задачі та побудова математичної моделі (етап формалізації); 2) дослідження математичної моделі; 3) інтерпретація отриманих математичних результатів, їх аналіз та корекція.

На етапі формалізації необхідно перейти від реальної економічної ситуації до іiї формальної моделі. Для цього спочатку потрібно визначити і чітко окреслити об'єкт дослідження. На цьому етапі виділяються такі моменти: об'єкт дослідження розбивається на елементи, що характеризують найістотніші властивості цього об'єкта і відповідають поставленій меті та конкретним умовам; кожному елементу ставиться присвоюється певна кількісна величина (економічні твердження виражаються за допомогою математичних символів); утворюється абстрактна система взаємопов'язаних елементів; аналізується повнота даних системи; виділяються основні зв'язки між окремими елементами системи. При цьому використовується математичний аппарат, перевіряється несуперечливість побудованої математичної моделі. На початковому етапі навчання студентів методам математичного моделювання не потрібно ставити за мету реалізацію всіх кроків етапу формалізації, оскільки це пов'язано зі значними витратами часу, а також 3 психологічною неготовністю студентів-першокурсників до повноцінногого наукового дослідження.

Отож, насамперед потрібно навчити студентів ставитися до текстової форми математичної задачі, як до результату моделювання реальної економічної ситуації, де відкинуті другорядні й залишені головні властивості об'єкта, які підлягають аналізу. 3 цією метою студенти вивчають умову математичної задачі і намагаються самостійно відновити несуттєві з математичного погляду властивості об’єкта, що можуть виникнути в реальній економічній ситуації.

На другому етапі студенти намагаються використовувати відповідний математичний апарат у розв'язанні поставленої математичної задачі, шукають і розробляють свій метод розв'язання. Після його реалізації важливо провести математичне дослідження результатів розв'язання задачі, оскільки головна мета моделювання реальних процесів полягає у необхідності передбачити нові властивості або результати.

На третьому етапі відбувається інтерпретація результатів та перевірка особливостей розв'язку задачі. Цей етап вимагає повернення до поставленої економічної проблеми. Потрібно перевірити відповідність отриманих результатів вихідній економічній ситуації, перейти від отриманих загальних тверджень до часткових, оцінити значення отриманого результату.

У традиційному курсі вищої математики основна увага приділяється етапу проведення математичного дослідження i недостатньо уваги іншим методам і прийомам складання математичної моделі, аналізу та інтерпретації. Проте саме ці питання становлять основні труднощі для студентів. Тому в процесі розв'язування прикладних задач основну увагу студентів зосереджуємо на побудові математичної моделі. Розглянемо цей вид роботи.

Нехай маємо проблему аграрного виробництва щодо визначення оптимального розміру оброблюваної площі землі господарства таким чином, щоб собівартість одиниці зібраної продукції була найменшою. Студентам на перший погляд здається, що математичний апарат, зокрема диференціальне числення, не має ніякого відношення до розв'язання цієї проблеми. Пропонуємо їм проаналізувати проблему.

Собівартість одиниці продукції - це відношення загальних витрат до кількості виробленої продукції. Оптимальний розмір оброблюваної площі землі - це розмір, за якого собівартість одиниці продукції найменша. Відомо, що загальні витрати складаються 3 постійних та змінних. Нехай змінні витрати складаються 3 витрат на обробіток грунту та на транспортування. Для визначеності розраховуватимемо витрати на обробіток грунту пропорційними площі, яка обробляється, а витрати на транспортування пропорційними добутку середньої відстані на перевезену кількість продукції. Введемо позначення: $S_{-}$собівартість, $x$ (ум. од.) - площа, $N$ 


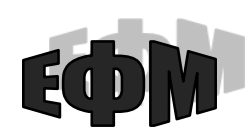

http://efm.vsau.org/

(ум. од.) - кількість урожаю з одиниці площі, $b, l_{- \text {коефіцієнти пропорційності }}(b>0, l>0), B_{1}$ (ум. од.) - постійні витрати, тоді матимемо математичну модель: $S=\frac{B_{1}+b x+l N x \sqrt{x}}{N x}$, або $S=B_{1} / N x+b / N+l \sqrt{x}$.

Отже, задача зводиться до знаходження мінімального значення $S$ як функції від $x$.

Під час математичного моделювання абстрагуються від якісної різнорідності моделі та реального об’єкта. Це узагальнення набуває характеру математичної подібності, яке породжується тотожністю математичної форми законів природи, тобто економічні закони $\epsilon$ різними, а математична форма їхнього запису - одна й та сама. Наприклад, закони спадної продуктивності факторів виробництва, спадної граничної корисності, спадної граничної схильності до споживання, що діють в економіці, $є$ за своєю природою різними, однак їх можна описати однією і тією ж математичною моделлю, яка характеризує тенденцію зростання зі спадною швидкістю. Тому вивчення великої кількості різноманітних за своєю природою явищ можна замінити вивченням обмеженої кількості математичних моделей.

Для формування умінь та навичок дослідженя економічних процесів доцільно розглядати різні способи розв'язування прикладних задач. Розв'язуючи одну й ту саму задачу різними способами, студенти вчаться аналізувати, моделювати та використовувати різні математичні методи для розв'язання побудованої моделі.

Математичне моделювання можна використовувати при вивченні всіх розділів вищої математики. Посібники $[7,8]$ для студентів економічних спеціальностей містять багато цікавих прикладних задач.

Висновки. Отже, математична освіта майбутнього фахівця економічної галузі має бути зорієнтована на розвиток математичної інтуїції, вмінь та навичок користуватись математичними поняттями і методами, які використовуються у фахових дисциплінах, знаходження оптимальних розв'язків реальних економічних задач. Неперервність математичної освіти вимагає як від студентів, так і від викладачів чіткого усвідомлення того, що математична освіта не закінчується із завершенням відповідного курсу дисципліни, а продовжується протягом усього періоду навчання. На заняттях 3 вищої математики поряд із математичними задачами і прикладами необхідно розглядати завдання, що імітують етапи реального дослідження; розв'язувати задачі, які найбільш близькі до обраного фаху студентів.

Цілеспрямоване навчання математичного моделювання допоможе сформувати не тільки цілісну систему математичних знань студентів, а й забезпечить ії професійну спрямованість, яка передбачає відображення в змісті курсу вищої математики професійно значущого для майбутнього економіста навчального матеріалу. При цьому фундаментальність і професійна спрямованість перебуватимуть в єдності.

\section{Список використаних джерел}

1. Гусак Л.П., Гулівата І.О. Математичне моделювання як засіб здійснення професійної спрямованості навчання математики на економічних спеціальностях ВНЗ. Науковий вісник Ужггородського університету. Сер. Педагогіка. Соціальна робота. Зб. наук. праць. 2016. Вип. 1(38). С. 105-107.

2. Дутка Г.Я. Фундаменталізація математичної освіти майбутніх економістів: монографія. Київ: УБС НБУ, 2008. 478 с.

3. Нічуговська Л.І. Адаптивна концепція математичної освіти студентів ВН3 i конкурентоспроможність випускників: методологія, теорія, практика: монографія. Полтава: РВВ ПУСКУ, 2008. $153 \mathrm{c}$.

4. Рум'янцева К.С. Міждисциплінарна спрямованість курсу вищої математики в економічній освіті. Фізико-математична освіта: науковий журнал. 2017. Вип. 1(11). С. 97-100.

5. Ткач Ю.М. Професійна спрямованість навчання вищої математики у системі економічної освіти. Дидактика математики: проблеми і дослідження. 2011. Вип. 35. С. 93-97.

6. Фомкіна О.Г. Удосконалення методики навчання математики в економічному вузі: шляхи, форми і засоби, перспективи: монографія. Полтава: РВВ ПУСКУ, 2008. 122 с. 
7. Алілуйко А.М. Вища математика у прикладах і задачах для економістів: Навчальний посібник / А.М. Алілуйко та ін. Тернопіль: ТНЕУ, 2017. 148 с.

8. Васильченко І.П. Вища математика для економістів: Підручник. Київ: Знання, 2004. 454 с.

\section{References}

1. Husak L.P., Hulivata I.O. (2016). Matematychne modeliuvannia yak zasib zdiisnennia profesiinoi spriamovanosti navchannia matematyky na ekonomichnykh spetsialnostiakh VNZ [Mathematical modeling as a means of implementing the professional orientation of teaching mathematics on economic specialties of higher educational institutions]. Naukovyi visnyk Uzhhorodskoho universytetu. Seriia: «Pedahohika. Sotsialna robota» - Scientific Herald of Uzhhorod University. Series: "Pedagogical Science. Social work», 1(38), 105-107 [in Ukrainian].

2. Dutka H.Ia. (2008). Fundamentalizatsiia matematychnoi osvity maibutnikh ekonomistiv [Fundamentalization of mathematical education of future economists]. Kyiv, UBS NBU, 478 [in Ukrainian].

3. Nichuhovska L.I. (2008). Adaptyvna kontseptsiia matematychnoi osvity studentiv VNZ $i$ konkurentospromozhnist vypusknykiv: metodolohiia, teoriia, praktyka [Adaptive concept of mathematical education of students of higher educational institutions and competitiveness of graduates: methodology, theory, practice]. Poltava, RVV PUSKU, 153 [in Ukrainian].

4. Rumiantseva K.Ie. (2017). Mizhdystsyplinarna spriamovanist kursu vyshchoi matematyky v ekonomichnii osviti [Interdisciplinary orientation of the course of higher mathematics in economic education]. Fizyko-matematychna osvita: naukovyi zhurnal - Physical-mathematical education: a scientific journal, 1(11), 97-100 [in Ukrainian].

5. Tkach Yu.M. (2011). Profesiina spriamovanist navchannia vyshchoi matematyky u systemi ekonomichnoi osvity [Professional orientation of studying higher mathematics in the system of economic education]. Dydaktyka matematyky: problemy i doslidzhennia - Didactics of Mathematics: Problems and Research, 35, 93-97 [in Ukrainian].

6. Fomkina O.H. (2008). Udoskonalennia metodyky navchannia matematyky v ekonomichnomu vuzi: shliakhy, formy $i$ zasoby, perspektyvy [Improvement of the methodology of teaching mathematics in an economic high school: ways, forms and means, perspectives]. Poltava, RVV PUSKU, 122 [in Ukrainian].

7. Aliluiko A.M. et al. (2017). Vyshcha matematyka u prykladakh $i$ zadachakh dlia ekonomistiv [Higher mathematics in examples and tasks for economists]. Ternopil, TNEU, 148 [in Ukrainian].

8. Vasylchenko I.P. (2004). Vyshcha matematyka dlia ekonomistiv[Higher Mathematics for Economists]. Kyiv, Znannia, 454 [in Ukrainia].

\section{Інформація про автора}

НОВИЦЬКА Людмила Іванівна - кандидат педагогічних наук, доцент кафедри математики, фізики та комп'ютерних технологій, Вінницький національний аграрний університет (21008, м. Вінниця, вул. Сонячна, 3, e-mail: li@vsau.vin.ua).

NOVYTSKA Lyudmyla - Candidate of Pedagogical Sciences, Associate Professor of the Department of Mathematics, Physics and Computer Technologies, Vinnytsia National Agrarian University (21008, Vinnytsia, 3 Soniachna Str., e-mail: li@ vsau.vin.ua).

НОВИЦКАЯ Людмила Ивановна - кандидат педагогических наук, доцент кафедры математики, физики и компьютерных технологий, Винницкий национальный аграрный университет (21008, г. Винница, ул. Солнечная, 3, e-mail: li@vsau.vin.ua).

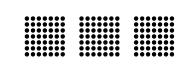

